\title{
わが国におけるドイツ製鉄道橋梁一歴史と現状一
}

\author{
信州大学工学部正会員 小 西 純一 \\ 首都园新都方鉄道（株）正会員 西 野 保 行 \\ 日石テクノロジー（株）淵 上 龍 雄
}

\section{A History of German-made Railway Bridges in Japan}

by J. Konishi, Y. Nishino, T. Fuchigami

\section{要旨}

わが国の橋梁史の中で特異な位置を占めるドイツ製鉄道橋梁について、トラス行を中心に 導入の経緯、桁の種類とその技術的特徴を述べ、さらに架設・使用・転用状洗、現存橋梁な どの調查結果を述べる。九州鉄道最初のトラス桁が、従来その存在を見落とされてきた 2 形 式のプラットトラスであることを確かめるとともに、ボーストリングトラスの所在と数量に 関して従来の定説を修正した。[構造物，鉄道橋梁，明治特代，ドイッ]

1.わが国におけるドイツ製橋梁

わが国におけるドイツ製橋梁の最初のものは道路 橋で、1873 (明治6) 作に大限長堀川に架設された 心晟橋であった。支間 $36.4 \mathrm{~m}$ のボーストリングトラ ス(bowstring truss, parabolic truss)で、格点は リベット結合であった。その後しばらくは輸入され た形跡がないが、明治20年代には、大貝の橋析が輸 入されることになる。そのさきがけとなったのが18 88（明治21）尔に輸人されたピン結合のトラス桁で、 大阪の天种橋，天満橋，木津川橋などに架設された。

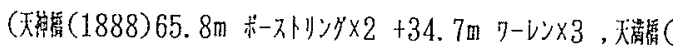

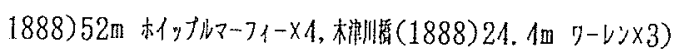
同じ仕に東京では皇居一莗橋に 3 ヒンジ充腹ア一チ が輸入・架設された。これらはいずれもハーコート 社(Harkort) の製作になるものであった1)2》。さら に、1889（明治22）作には古河铦業足尾銅山の占河 橋に、同じくハーコート製のピン結合ボーストリン グトラスが翰入・架設された。

九州に鉄道を数設するため、九州鉄道会社が設立 され、顧問技師にドィツ人鉄道技師ヘルマン・ルム シェッテル(Hermann Rumschōttel) が招聘されて、 建設が始まった。輸入が必要な資材、すなわち、レ ール、機関車、本雨、橋桁などはことごとくドイッ に注文され、ここに、本州の英国式、北海道の米国

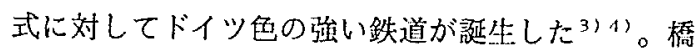

桁に関しては、最初の開通区間にウニオン・ドルト ムント製のトラス桁が染設さ机たが、それ以後は八 ーコート製のボーストリングトラスが多数、線路の 伸長とともに各地に架設されていった。もちろん、 プレートガーダーなどもドィツ流のものが架設され た。

九州以外でドイツ製の橋桁を架設した鉄道橋は少 ない。ルムシェッテルが指導した別子钩山鉄道の足 谷川橋梁は九州铁道のものと同系のボーストリング トラスであり、機関本などもドイツ製品が使用され ている。

また、ルムシェッテルの原案に基づいてドイッ人 支師バルツァーが設計した東京市街線に接続し、甲 武鉄道最後の建設区間となった厅世橋一飯田橋閌の 小石川架道橋と昌平橋架道橋には八ーコート製のプ レートガーダーとトラス (1904年製) が架設されて いる。このほかにはドイツ製の鉄道槅梁はなく、結 局、ルムシェッテルが值接、間接に関与した鉄道だ けがドイツ製橋梁を採用したことになる。

\section{2. ドイツ人技師の招聘と儿州鉄道}

九州鉄道の創立委負会はプロイセン国有鉄道機械 監督ヘルマン・ルムシェッテルを顧䦓技陑として招 聘し，ルムシェッテルは1887（明治20）年12月に着 任した。 
ルムシェッテルの招聘について、吉沢まことは、 次のように述べている5!。『…創立委員会は、社長 人事については政府に人物の推虛を依頼し、その結 果、農商務省商務局長であった高橋新吉が社長とな った。この高橋社長は早くからドイツの鉄道技術に 着目しており、優秀な技饰をドイツから招きたいと 政府に熱心に請願し、ルムシェッテルの招聘に成功

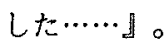

顧問技師としてドイツ人のヘルマン・ルムシェッ テルが着任した結果、当初、九州鉄道はドイツ製品 を多用している。すなわち、橋梁はトラス、敛桁と もウニオン社とハーコート社製、レールは九鉄 1 号 （50ポンド第10種）と呼ばれるドイツの軽鉄道用レ ールに準じた設計で、ウニオン製であるが、英国の カメル社にも造らせている(゙。機関車はホーエンツ オレルン製，続いてクラウス製を入れ、客車はバン デルチーペン製、……いった具合であった。ルム シェッテルは母国のて業製品翰出に大いに貢献をし たのである。

しかしやがて、輸送罢の増大に伴う改良・增借は アメリカの製品によって行われるようになる。

3. ドイツの橋梁製作会社.

19紀におけるドイツの橋梁製作会社としては、 次ぎの 6社が主なものであっだ。これらのうちわ が国で製品が磼認されているのは3）と6)で、1)はア プト式機関車、2)6)はレール、5)は内然機関本をわ が国の鉄道に供給している。

1)エスリンゲン Haschinenfabrik Esslingen

2)グーテホフヌングスヒュッテ

Die Gutehoffnungshütte
3)ハーコート Die Gesellschaft Harkort
4)ホルツマン Philipp Holzmann \& Cie
5)マン
M. A. N.
6)ウニオン Gesellschaft Union in Dortmund

4. 九州鉄道最初のトラスくウニオン社製プラット トラス>

4.1 通説への疑問と資料の存在

九州鉄道といえばハーコート社のボーストリング トラスを思い浮かべるが、九州鉄道で最初に建設さ れた第 3 工区の旭川と干藏川に架設されたトラス桁 は、ウニオン社の設計製作になるピン結合プラット トラスであった。

ところが、鉄道橋についてのバイブル的存在の、 久保田敬一「本邦鉄道橋梁ノ沿革二就テ」(1934) ${ }^{81}$ では p.11.で、

『本会社線門司八代問及鳥栖長䐀間二架セ儿構桁八 22橋アリ、其ノ重ナルモノハ千藏川二架セル 100 以 5速、150呎 4速、30呎 2連、遻賀川二架セル 100 呎 4連、150呎 5連等ナリ、此等22橋梁二架セル 1 00吹及 150吹搆桁八独晩国はーこーと会社ノ製作二 係ルぼーすとりんぐ型檄桁ニシテ英国型卜全ク其ノ 趣习罪二セリ。』

と述べ、千歳川橋梁のトラス桁をハーコート会社鹠 作のボーストリング形とした。p. 31の本邦国有鉄道 構桁一覧表 其ノ四でもそのようになっている。旭 川は記载されておらず、結果的にウニオン社製のプ ラットトラスは、それ以降、国鉄の橋梁史に現れな い『幻』の形式となってしまったのである。 著者らは、前報》で、『明治工業吏』，鉄道篇

写真 1 初代干歳川橋梁(1890-1914), 1913年架け替え工事開始直後の撮影, 文献15）より転載。

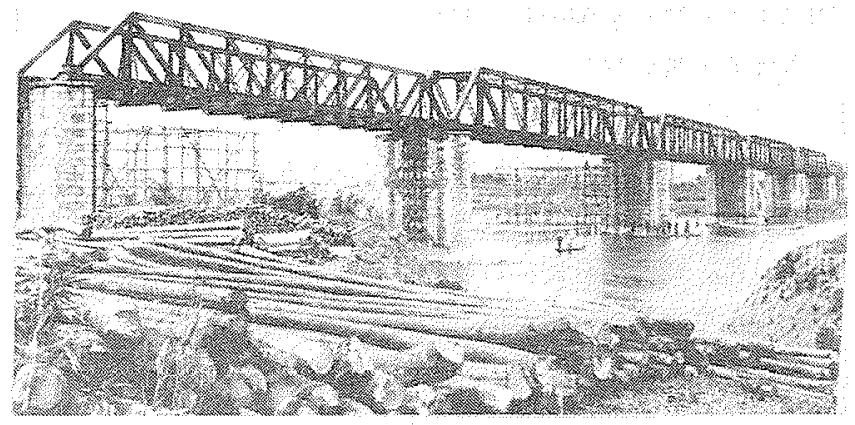




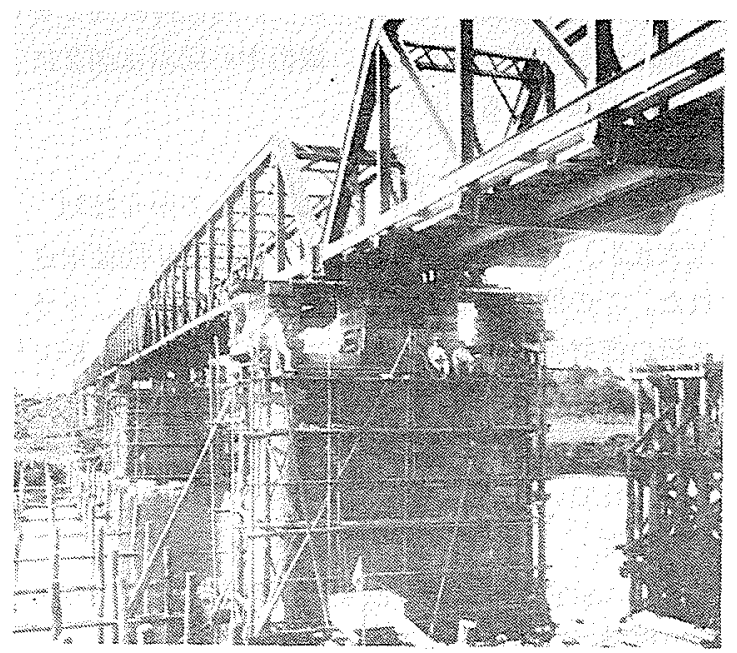

写真 2 架け替え工事中の $45.3 \mathrm{~m}$ 析。桁を仮受けし て床石を交換中。床組に注目。文献15）より。

$(1926)^{10)}$, p. $514 . の$

『構桁八径間 100 吹及ビ 150 呎ノ 2 種ニシテ、型式 八鳥栖久留米問旭川二架シタル徍間 100 呎 1 連卜千 歳川二架シタル径間 100吹 5連、150吹4連ハぷら っと式ナレドモ其ノ他八総べテばうすとりんぐ型ナ リ』

という記述と、一枚のかなりリアルな絵図「筑後川 䤽橋之図」いを手掛かりにして調查を進め、プラ ットトラスの存在を確信した。その後、次の根本資 料を参照することができ、問違いないことを確かめ た。すなわち、旭川と千歳川に架設されたトラス桁 がプラット形であることは、明治27年 7月31日現在 『全国各鉄道橋梁及び㯌道明細表』121によって明 らかとなった。ウニオン製であることは、『千歳川 橋梁鉄标架換工事概要』(1914) ${ }^{33)}$ と、Foerster:” Taschenbuch für Bauingenieure (1921), p. 1872 $-3^{14)}$ に記述があり、現存する桁の陽刻もそれを裹 付けている。桁の構造についても、Foersterの本に 部分図が載っている。また、『筑後川橋梁鉄析架換 土事写真帖』15)には鮮明な写真が多数あって、九 州鉄道最初のトラス桁の姿を伝えている。さらに前 報で報告したように熊本県植木町には現物が保存さ れている。

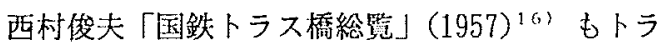
ス桁に関する重要な基本文献であるが、上述の久保

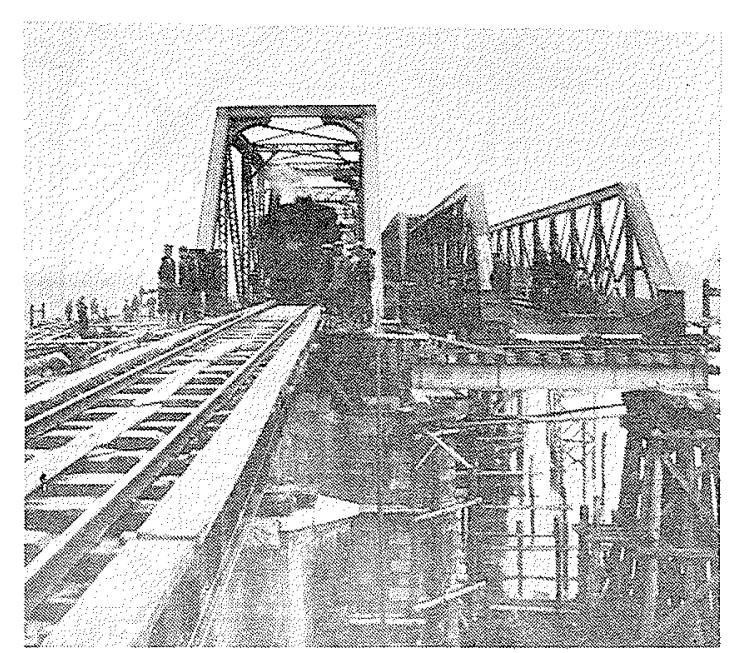

写真 3 横取り架け替えが終って試運転中。仮桁上 の32.0n 桁の端横桁に注目。文献15）より

田論文をべースにしており、同じ誤りを踏熋してい る。铁道橋についてのこのような権威ある論文での 斐りは、これらを引用したその後の多くの著作に影 を落とした。最近の出版物では、守田久盛・神谷牧 夫『鉄道路線変せん史挆訪IV九州の鉄道 100年』(1 989) 171 、九州旅客鉄道『九州の鉄道 100年記念誌

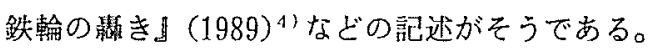

\section{2 ウニオン社製プラットトラスの構造}

九州鉄道における開通当初の設計荷重は、図 1 に 示すもので、タンク機重連の前後に2 朝車を連結し たものである ${ }^{18) 。 ~}$

ウニオン社製の桁は、径間32.0m のポニープラッ トトラスと $47.3 \mathrm{~m}$ のプラットトラスの 2 種類で、同 じ設計指針によっており、構造細目は共通といって よい。上弦材之端柱とはП断湎、下弦材は關断面で、 これらは一体の枠組みを形成しており、これに带材 の斜材と I 形断面の垂直材がピン結合されている。

このトラス桁最大の特徵は、床組が下弦材の下に 取付けられていることであって、わが国の鉄道橋で

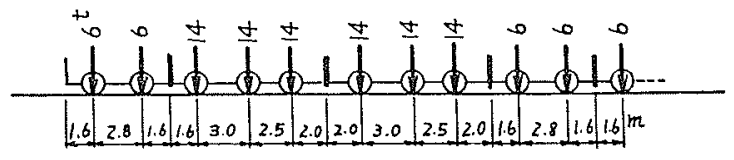

図 1 九州鉄道の設計活荷重 ${ }^{181}$ 

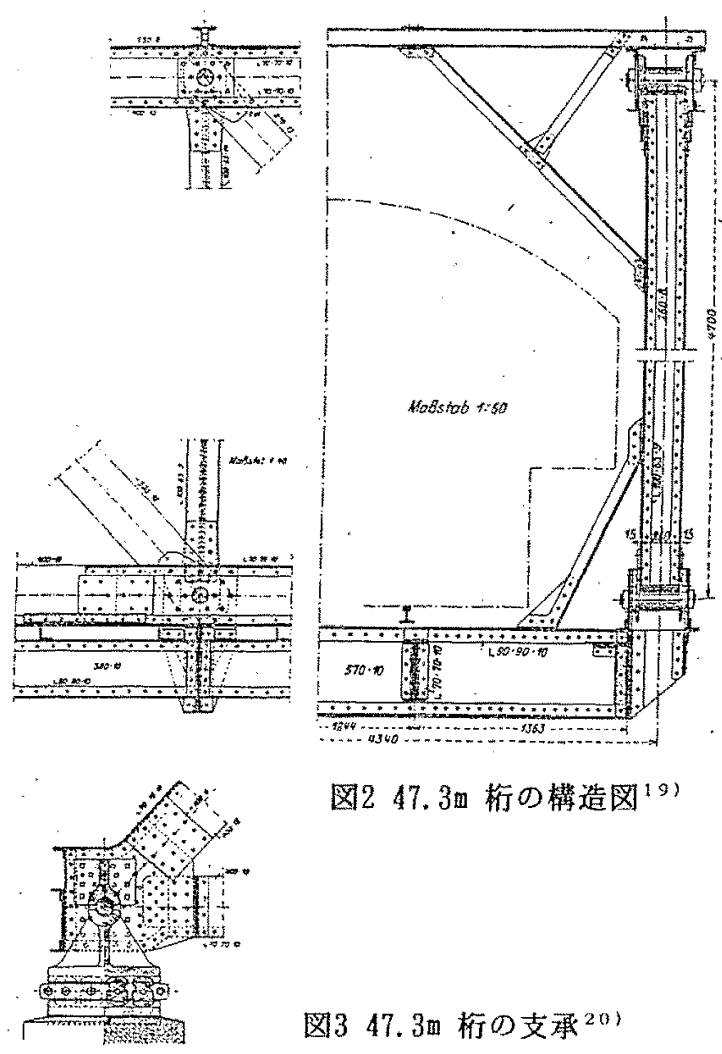

図2 47.3n杵の搼造図 ${ }^{191}$

図347.3m 枌の支承 ${ }^{201}$
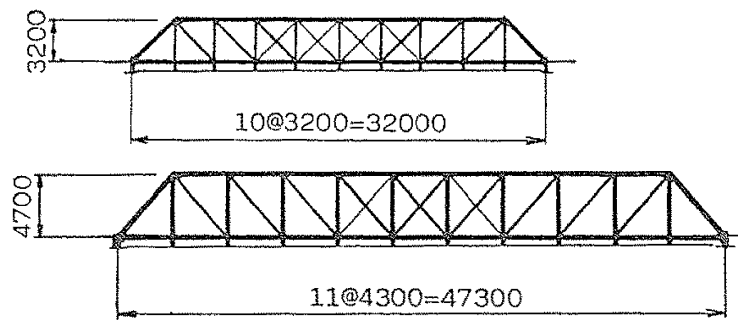

国4ウニオン析のスケルトン は他に洌を見ない（図2 ${ }^{19}$ ，写真 2，3）。床組 は当時の英国系の椎と比べると本格的で、立派な端 横析を借えている。支承は鋳鉄製で、下弦材内部に はまり込む形となっており、桁とはピンで連結され、 可動端倪は口ッカー支承である（四 $3^{20) ） 。 ホ ゚ ニ ~}$ 一トラスのs say bracingの処理も特幑あるものであ る(写真 4,5 )。

\section{3 スケルトン}

著者らが推定したスケルトンは図 4のようである。 $32.0 \mathrm{~m}$ 析は植木町の保存析の奏测值から格間長之高

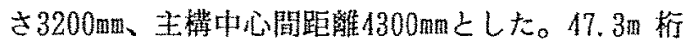
は、高さと主粠中心間距離は図 2 記载の寸法によっ てそれぞれ4700m，4340mmであり、格閒長は図 2 か ら割り山して4300m出した。綐析中心間隔は図 2 に より1244mmである。

\section{4 使用状況（表 1，2）}

1890（明治23）年3月1日に開通してから1914 （大正3）年 1月撤去されるまでの約24年間使用さ れた。この間に鉄道輸送量は飛躍的に増大し、トラ 不桁の部材強度が不足しはじめ、また、47.3田 栴で は桁の高さが小さく、建築限界を維持できなくなっ て撤去の理由となった。クーパー設計のトラスと取 替えら扎ている。

\section{5 䎐用}

表 1 に示すように磨本鉄道（山鹿温鼠鉄道）の菊 池川橋梁に32.0m 杕 4連が転用され21)、1920（大 正9）年から1960（沿和35）年までの40年墹使用さ れたほか、佐賀県下、千歳川橋梁の下流約1 1 作の 人道橋にも $32.0 \mathrm{~m}$ 桁 1 連が撤去後ただちに転用され た22)。1914（大正3）作当時そのままスクラップ にすることはまれであったから、残りの32.0m 桁 1 連と $47.3 \mathrm{n} 4$ 連もどこかの橋梁に転用されたもの之 思われるが、今のところ転用先不明である。

\section{6 現存している32m 桁}

山鹿温泉鉄道菊池川橋梁に転用された $32.0 \mathrm{~m}$ 桁 4 連のうちの1連が鉄道廃让後宮原の駅跡に保存展示 されている（写真 4，5）。原形は10パネルだが、 現橋は保存時に中央の3パネルを省いて7パネルに 改造されている。絴析の鋼材に UNION HORST N32と いう陽刻がある。山鹿温宗跌道の記念物として保存 されたものと推测されるが現地には説明版などはな い。単に山鹰舅泉鉄道の記念物というに止まらず、 九州の鉄道にとって、正に記念すべき橋析であり、 よくぞ牫してくれたものと感謝しなければならない。

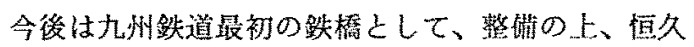
保存の道を開きたいものである。

5.ハーコート社のボーストリングトラス

5.1 ハーコート社のピン結合トラス

当時、ドイツ国内で架設されるトラスはリベット 結合が一般的であったが、輸出用としては組み立て が簡単なピン結合トラスがかなりの比重を占めてい た。その中でも特に有名で成功したのがハーコート 社のGelenkbolzen-Bricken(The Harkort system of 


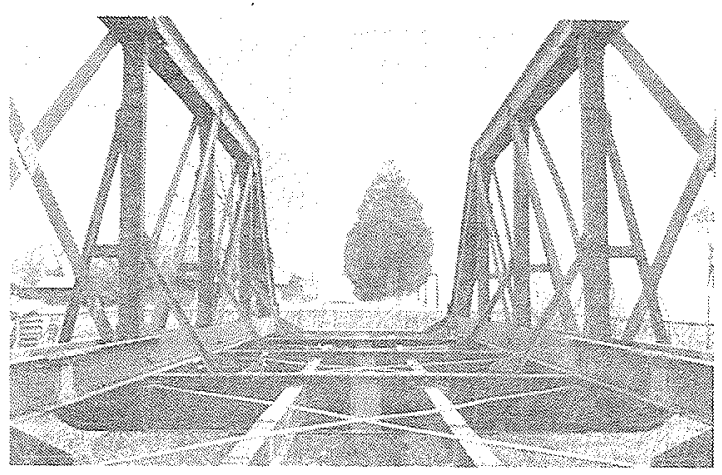

写真 4 山鹿温泉铁道宮原駅跡に保存されているウ

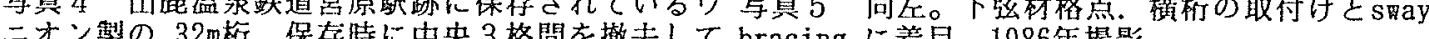
$22.4 \mathrm{~m}$ に短縮されている。1986年撮影。

pin Bridges)と称するピン結合トラスである ${ }^{23)} 。$ スパン $80 \mathrm{~m}$ 位までの平行弦トラスまたはボーストリ ングトラスで、当時の低開発国：日本、シャム、ス マトラ、フォルモサ、トランスバール、ブラジル、 エクアドル、といった国々に大鼠に翰出された。同 社の1889-1898 年の10年間の橋梁と鋼棈造の翰出奏 績をみると日本向けが最も多く6295ton であり211、 そのうちボーストリングトラスは1889(明治22) 年 から1897年の間に翰出された3006ton である261。

ハーコート・ピントラスシステムの最大の特長は、 現場における各部材の接合はすべてピンあるいはボ ルトナットで行われ、㲛練したリベット工なしで短 時間のうちに桁の組み站て・架設が実行できる点に あった251261。

ボーストリングトラスの上泫材格点は放物線の上 にあり、アーチとしての作用があるから、均等荷重
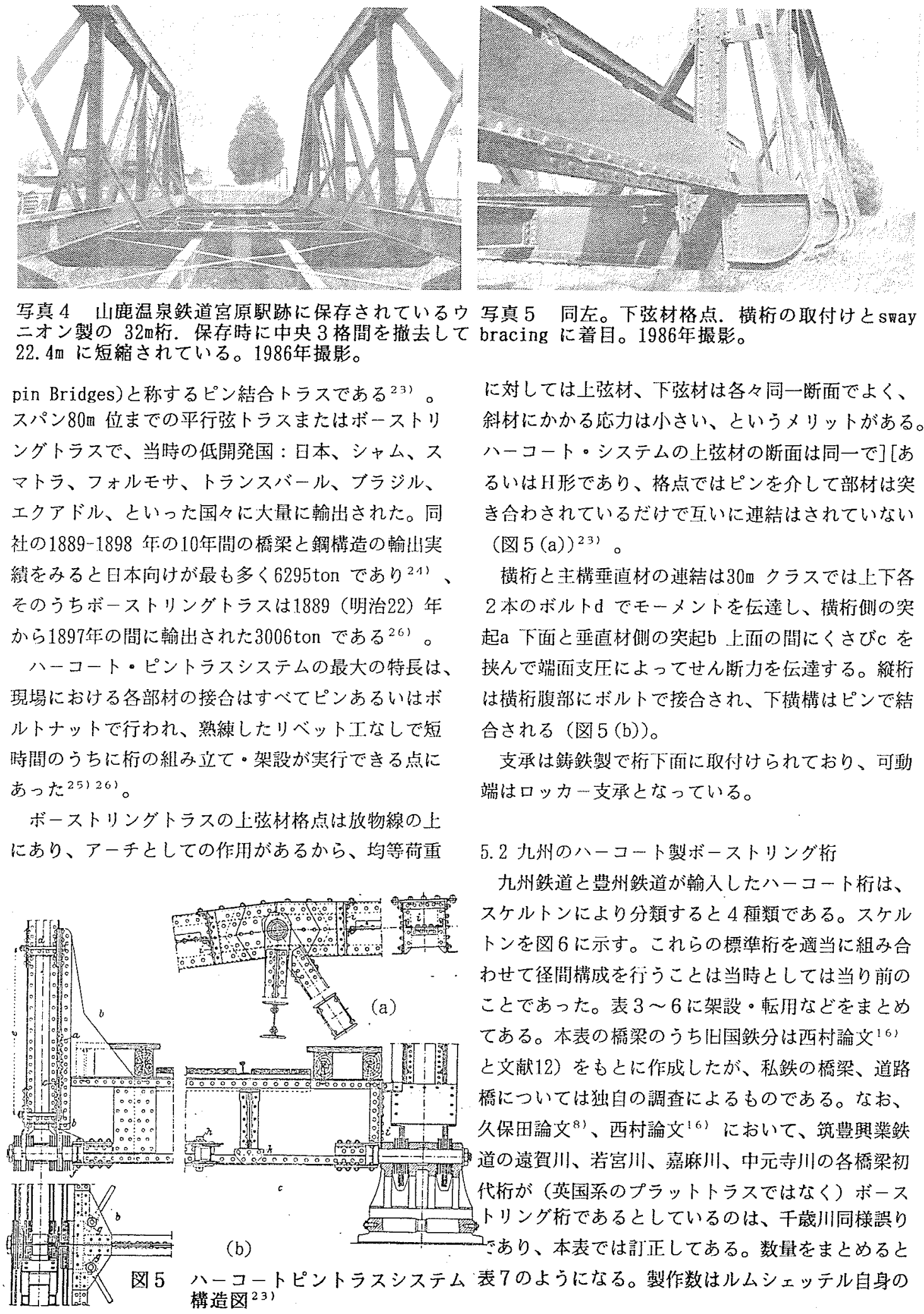

$\begin{array}{ll}\text { 写真 } 5 & \text { 同左。下弦材格点. } \\ \text { bracing } & \text { 着目。1986年撮影。 }\end{array}$

に対しては上弦材、下弦材は各々同一断面でよく、 斜材にかかる地力は小さ、というメリットがある。 ハーコート・システムの上弦材の断面は同一で $][$ あ るいはH形であり、格点ではピンを介して部材は乫 き合わされているだけで互いに連結はされていない (図 5 (a)) ${ }^{231}$ 。

鼔桁と主構垂㨁材の連結は30m クラスでは上下各 2 本のボルトdでモーメントを伝達し、横桁侧の哭 起a下面と重直材例の突起b上而の間にくさびc を 挟んで端面交厈によってせん断力を伝達する。緥桁 は横行腹部にボルトで接合され、下横構はピンで結 合される(図 5 (b))。

支承は鋳鉄隼裂で析下面に取付けられており、可動 端はロッカー支承となっている。

\section{2 九州のハーコート製ボーストリング胻}

九州鉄道己豊州鉄道が翰入したハーコート桁は、 スケルトンにより分類すると 4 種類である。スケル トンを図 6 に示す。これらの標準桁を適当に組み合 わせて径間棈成を行うことは当時としては当り前の ことであった。表 3 〜 6架設・転月などをまとめ てある。本表の橋梁のうち日国鉄分は西村論文 ${ }^{161}$ と文献12）をもとに作成したが、私鉄の橋梁、道路 橋については独自の調盉によるものである。なお、 久保田論文 ${ }^{81}$ 、西村論文 ${ }^{(6)}$ において、筑豊與樂鉄 道の遠賀川、若宮川、勎䄶川、中元寺川の各橋梁初 代桁が（英国系のプラットトラスではなく）ボース トリング桁であるとしているのは、千歳川同様蛙り (b)

ごあり、本表では偝正してある。数量をまとめると ハーコートピントラスシステム'表 7 のうになる。製作数はルムシェッテル自身の 棈造図 ${ }^{231}$ 

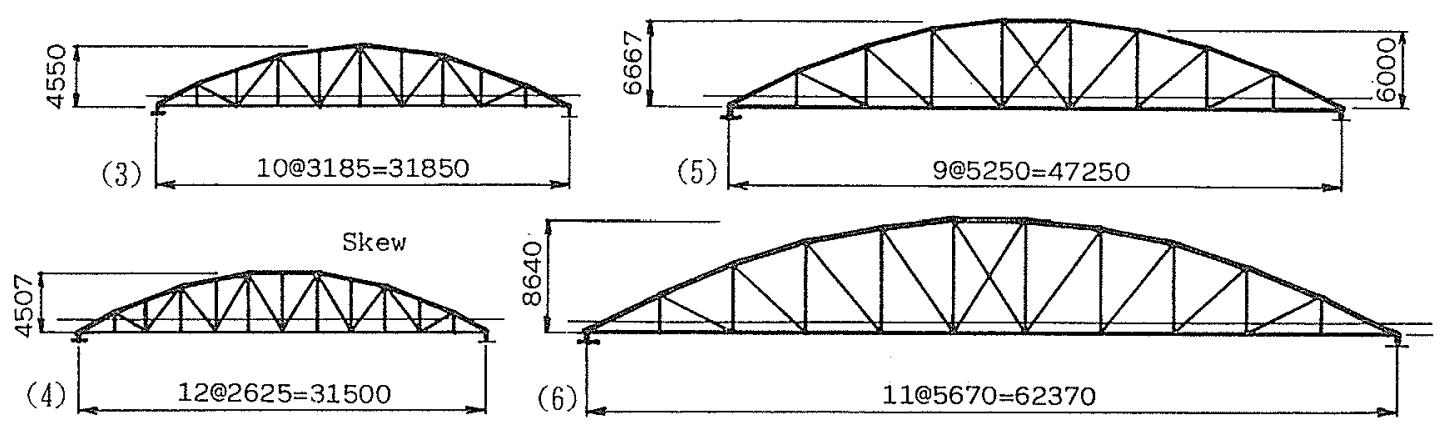

図6 九州鉄道・豊州鉄道のボーストリングトラス のスケルトン

記述（別子鉣山敇道の1連を含めてある）261と一 致している。

表 7 九州のボーストリング析

表№ 支間 格間数 製作数 転用数 現存数

\begin{tabular}{rrrcrrr}
3 & $31.85 \mathrm{~m}$ & 10 & F14 e 31 & 35 & F1 e6 \\
4 & $31.50 \mathrm{~m}$ & 12 & F 2 & & 0 \\
5 & $47.25 \mathrm{~m}$ & 9 & F11 e 3 & 13 & F1 e 1 \\
6 & $62.37 \mathrm{~m}$ & 11 & e 1 & e 1 & 0 \\
\hline 計 & & & 62 & 49 & 9
\end{tabular}

これより合計62連が製作され、これまでに判明して いるだけで49連が転用され、9連が現存しているこ とがわかる。なお、これらの桁の下弦材には、2種 類あって、1890年頃架設されたものではflat barで あるが、1894年以降のものはeye bar に変った。 eye bar の形状は英、米のものとは異なる独特のも のである(表中数値闌の Fはflat bar、eはeye bar を示す）。

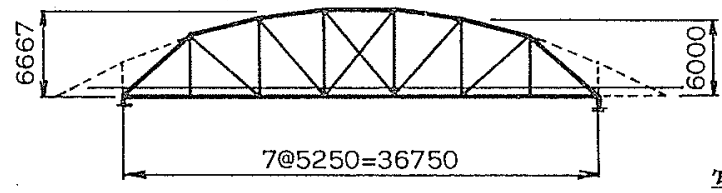

図 7 長野電鉄市川橋梁のスケルトン
なお、使用鋼材はわが国に架設されたものは、す べてAachener Hütten-Aktien-Verein の製品で、

A. H. A.V.という陽刻がある。

\section{3 ボーストリング桁使用状況}

小型機関車相当の設計荷重に対して設計されたも のであったから、明治後期になってからの輸送量の 伸びと機関車の大型化によって、幹線の橋梁ではた ちまち弱小桁になってしまった。遠賀川のものが19 11年に撤去されたのを皮切りに、幹線筋のものが20 ～26年間、田川線のものが27 31年間、平均で約 25 年使用されて撤去されている。

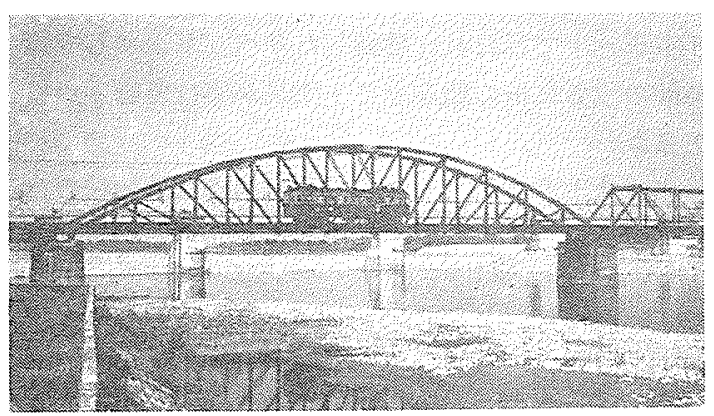

写真 6 京福永平寺線九頭竜川橋梁の $63.37 \mathrm{~m}$ 析. 19 60 年㥧. 村上温撮影

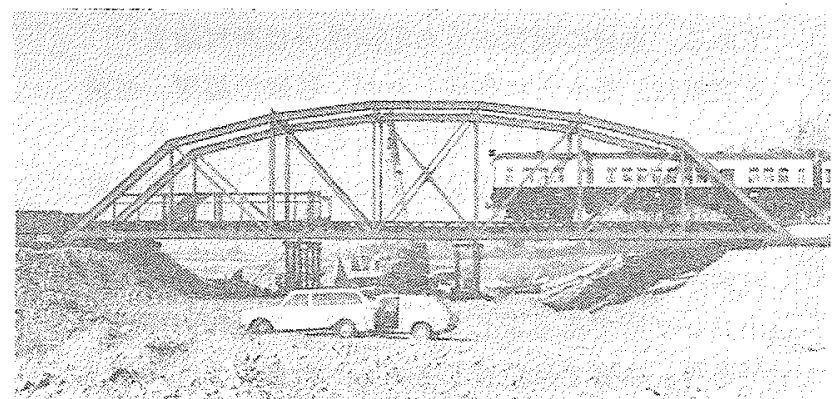

写真 7 長野電鉄市川橋梁, 47.25m析の短縮改造. 1974年，長野電鉄田中守提供

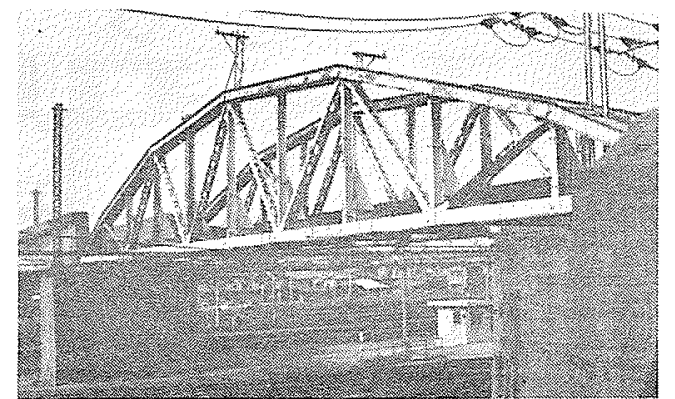

写真 8 大坪跨線橋 31.85 标 1986.11 掫影 下弦材はフラットバーである。 


\section{4 ボーストリング析の転用}

撤去された桁がそのままスクラップになることは むしろまれで、大多数は、中小私鉄の橋梁や跨線橋、 道路橋などに払い下げ・転用された。と言うのも撤 去の理由は荷重增大による耐荷力不足であって、材 質的な寿命ではないからである。残り少ないとは言 え、今日われわれが初期の橋桁を見ることができる のは、この転用のお陰である。これまでに判明した 転用枌を表 $3 \sim 6$ に揭げる。すでに做去されて現存 しないもの数例を紹介しょう。

1)京福永平寺線九頭竜川橋梁 わが国に翰入され たボーストリング鉄道桁としては最大の支間 $62.37 \mathrm{~m}$ 唯一の桁が田川線から撤去された後、払い下げられ て架設されていた。写真 6 は村上温氏撮影の1960年 頃の姿である。

2)南海高野線紀の川橋梁 47.25mの桁であるが、 下弦材取替えを初め、各部を補強して設計荷重を 22 6 とし ${ }^{271} 、 1924$ 年開通、1969年撤去。なお、文献 28）所載の図でも下弦材寸法が標準の $332 \times 24 \mathrm{~mm}$

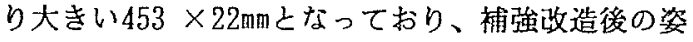
と思われるが本橋とは異なっている。

3)長野電鉄市川橋梁 四7に示すように、雨端の パネルを撤去して短縮補強したものである291。写 真7に見るように普通の曲弦プラットトラスに近く なった。1922年開通、1972年鈑桁に取替え撤去。

4)海陸連絡設備の可動橋 関森連絡線の可動橋は 九州側の小森江はボーストリング标、本州側の下関 は官設鉄道の英国式ポニーワーレン桁を改造したも のであった。1919年に最初のものが完成し、1942年 に関門トンネルが開通してその役目を終えた ${ }^{30) 。 ~}$

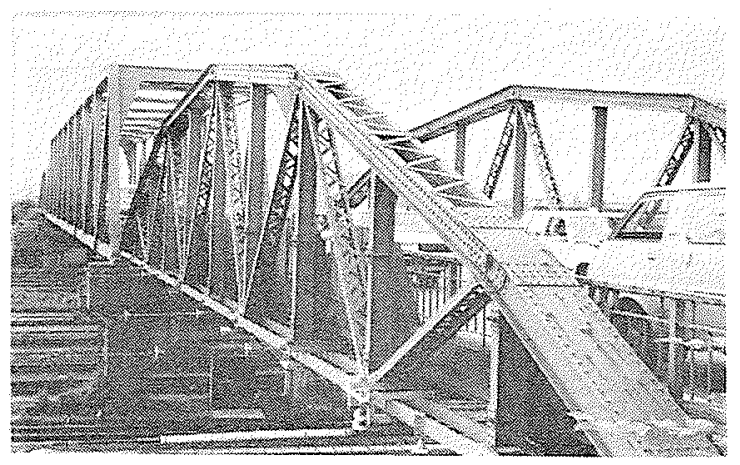

写真 9 第 2 上条市道跨線橋，1985.6撮影 昖幅・補強されている。

\section{5 現存するボーストリング桁}

見存しているのはすべて転用桁で、31.85桁が 4 橋 7 連、47. 25 桁が 2 橋 2 連である。

1)大坪跨線橋 山陽電気軌道が山陽本線幡生操車 場を乗り越えていたもので、1971年軌道廃止後も現 存しているが、撤去は時間の問題であろう。上弦材 にカバープレートが追加されているが、下弦材がフ ラットバーであり、1890年輸入の 31.85 桁としては 現存唯一である（写真 8)。

2)第 2 上条市道跨線橋 長岡操車場に架かり、中 央が60m トラス、両侧が31.85mのボーストリング桁 である。㹡幅してある。1965年頃かなり補強され、 上弦材側面のリベット、正面のカバープレートが目 立つ（写真 9)。

3)小久保跨線橋 西明石駅に架かる31.85mのボー ストリング桁 2 連で、橋床をのぞいて原形を良く保 存している（写真10）。改築の計画がある。

4)上田市の大石橋 丸子鉄道が建設した橋を、鉄 道廃止後、道路橋に改造したもの。これも改造は軽 微である（写真11）。

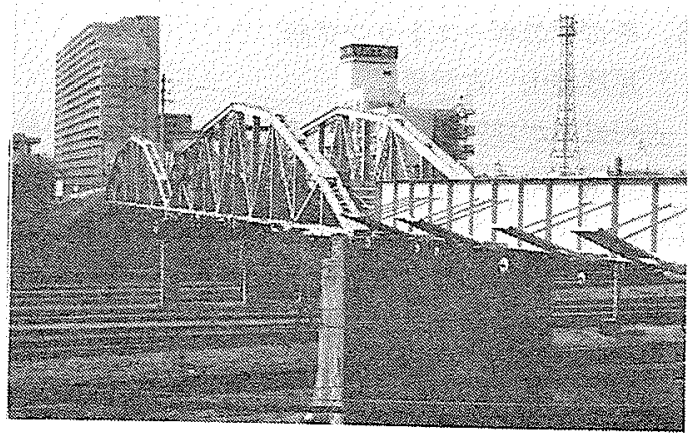

写真10 小久保跨線橋 $31.85 \mathrm{~m}$ 析 1991.2 撮影 原形を良く残す。

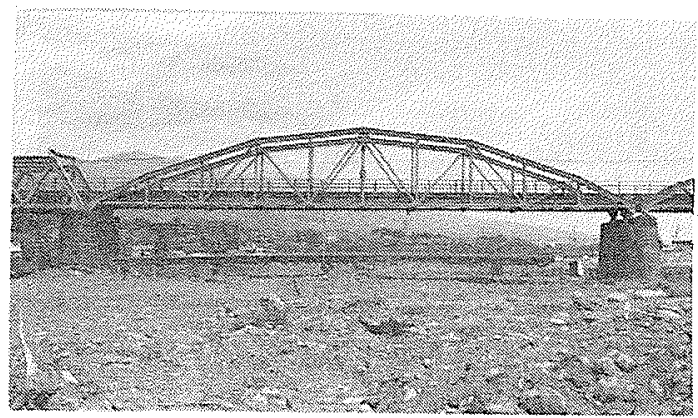

写真11 大石橋 31.85 析 1984.5 撮影

左は英国製ポニーワーレントラス 4 連。 


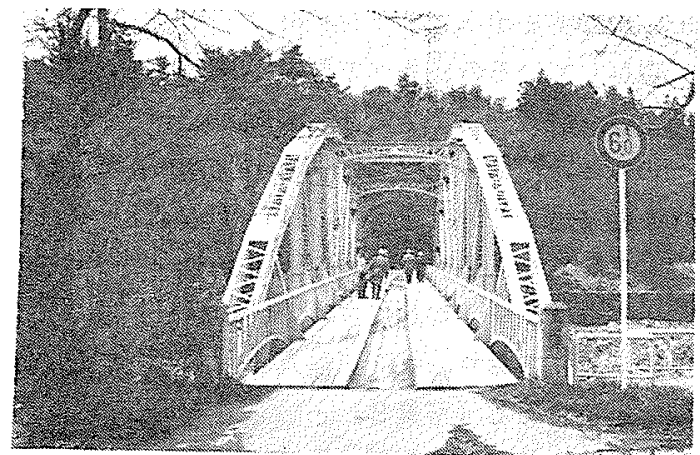

写真12 切立橋 47.25 m析 1987.4 撮影.

5)切立橋 日橋川に架かる東京電力猪苗代第 4 発 電所の専用線の橋であったが、現在は線路はなく、 道路橋として使われている。橋床面は木板張りで、 改造の跡は全く見られない。47.25析の原形である （写真12）。

6)陸田跨線橋 稲沢操車場の北端に架かる跨線橋 で、下弦材がeye bar の47.25桁である。下弦材が eye bar の 47. 25m桁は現在まで当橋しか発見されて いない（写真13）。

\section{6. その他のボーストリング桁}

\section{1 足尾銅山 古河橋}

古河鉱業が1890年12月に完成させた支間48m の軌 道併用橋であって純粋の鉄道橋ではないが取り上げ たい。ハーコート社と高田商会の銘板がついており、 九州鉄道のものとは上弦材の断面が異なっている。 喠道廃止後、補強されて、近年まで大型トラックが 頻繁に通行していた（写真14）。現在は保存目的で 歩道橋となっている。

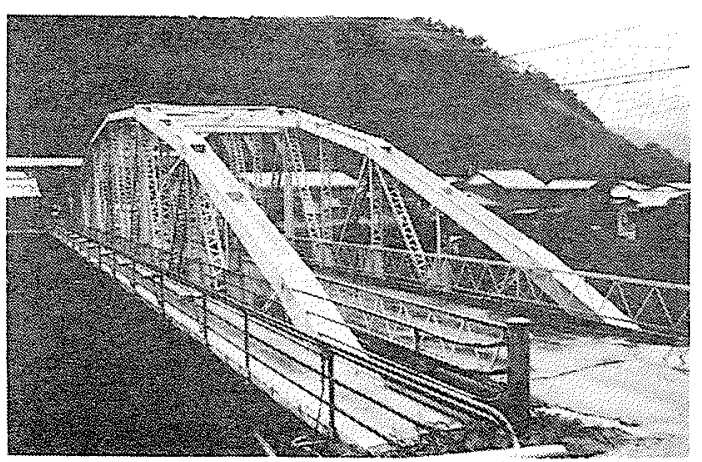

写真14 足尾町古河橋 1988.6 撮影 上弦材断面はH形である。

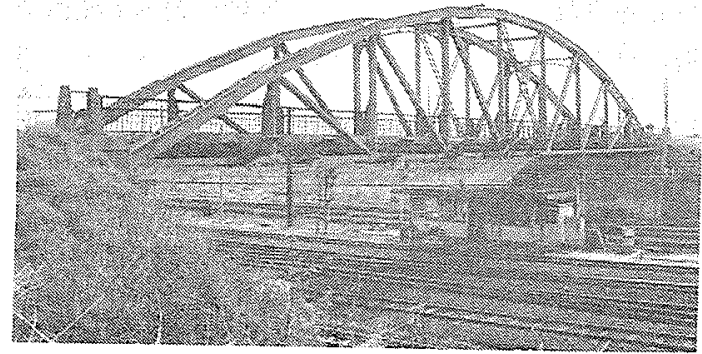

写真13 陸田跨線橋 47.25m 析 1984.4撮影

\section{2 別子鉱山 足谷川橋梁}

$762 \mathrm{~mm}$ ゲージの別子銛山鉄道が終点端出場付近で 国領川を渡る橋梁で、1893（明治26）年に架設され た。ルムシェッテルが指導をしたもので、ドイッ・ クラウス製の小型機関車とともに、九州のものより 一回り小形のハーコート製ボーストリングトラスが 導入されたのである。 $60^{\circ}$ の斜橋で、主構中心間距 離3.540m、一端の格間が短い31）（図 8、写真15）。 1977年に廃橋となったが、1991年に「マイントピア 別子」という施設の中の橋として復活した。

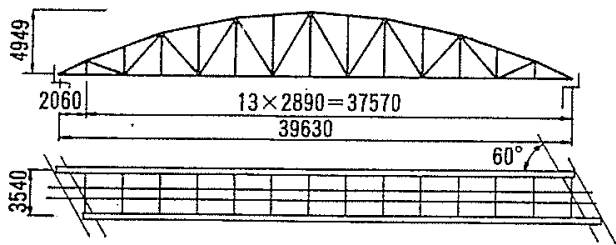

図 8 別子鉱山鉄道足谷川橋梁のスケルトン

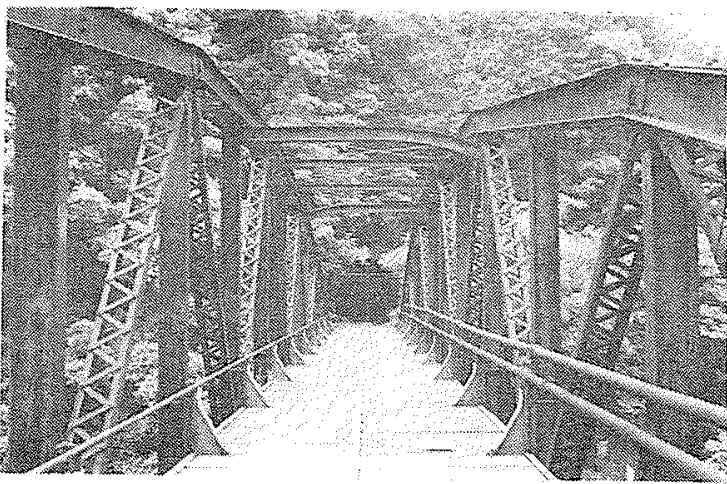

写真15 別子鉱山鉄道足谷川橋梁，九州之同系の斜 橋 1988.6 撮影 


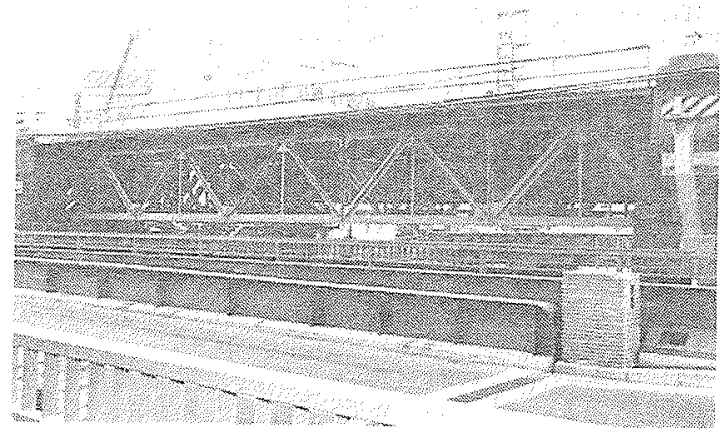

写真16 小石川橋梁のトラス 1989.3 撮影

\section{7. 甲武鉄道飯田橋・万世橋間の橋梁}

1904年に御茶ノ水まで複線化して電車運転を延長 した甲武跌道は、さらに神田までの政設免許を得て 工事を続行したが、1906年政府貿収となり、工事は 鉄道庁の東京市街線建築事務所に引き継がれた。小 石川架道橋は1904年に御茶ノ水まで複線化した時の 開通で、見在は緩行線として使われている。98年間 高密度電車運転を支えてきた訳である。架道橋部分 は 2 主析複線下路プレートガーダー、河川部は策線 上路ワーレントラス並列となっている。架道橋 1 径 閆+橋梁 1 径䦌+架道橋 2 径間という径間镂成で、 プレートガーダー、トラスとも、従来わが国で架設 されたことのない特徵ある設棓である。トラス桁で は、上下弦材はウェブ1林の Tまたは逆T断面であ り、各点部ではガセット板ではなく、別の大型ウェ ブ板をもってきて、これに各部材を鋲接してある

（写真16,17）。この手法は先に日本鉄道が阿武隈 川、隅田川のトラスに採用した。これらは英国の八 ンディーサイド社の設部・製作として知られている。 小石川のトラスは、部材断面寸法、スケルトンとも メートル制位で設計されている（図9）。しかし径 闒は25.400凸 となっていて、ちょうど1000inch= 83 ft4in になり、フィートの方でも切りが良い数值と なっている。水道橋寄りのプレートガーダーでは、 補㴊材の間隔が析高よりもかなり大きいのが目につ く。また、桁の吷に大型の銘板をつけている。

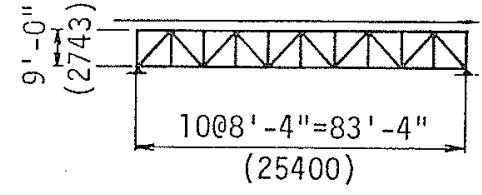

図 9 小石川橋梁トラスのスケルトン

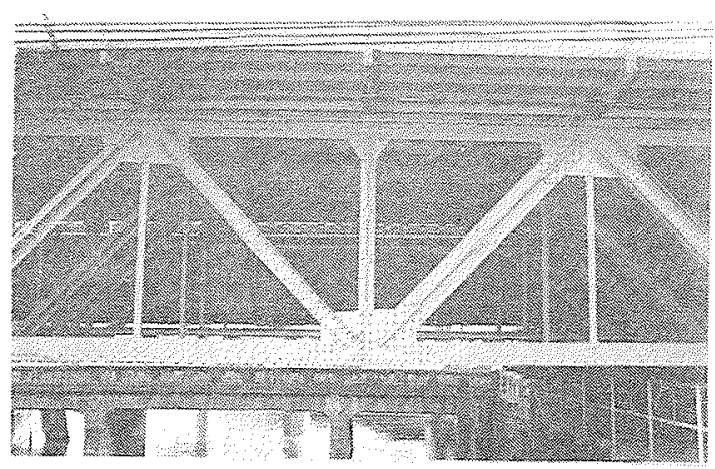

写真 17 小石川橋梁 格点の構造に特色がある。

昌平橋架道橋も、1904年ハーコートという銘板を つけているが、開通は国有化後の1908年であった。

\section{8.まとめ}

（1）わが国で最初に架設されたドイツ製の鉄道トラ ス桁は、ハーコート製ボーストリング形ではなく、 ウニオン製ピン結合平行弦プラットトラスであった。 その棈造的特徴は横析を下弦材の下に吊っているこ とで、桁座面〜レール面間の高さを低くできる。し かし、このような搆造は少くともわが国の敛道橋に 再び登場することはなかった。

（2）ハーコート社のピン結合トラスシステムの桁は 九州䑨道で採用され、九州各線に多数架設された。 また、是尾銅山と別子銅山でも 1 橋ずつ採用してい

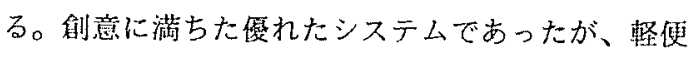
鉄道问きであって、輸选显の多い幹線用ではなかっ た。その後の翰送黑の伸びは当初の予测をはるかに 越えるものであったに䗬いない。

ピン結合はわが国では英、独、米のいずれの流儀 も成功せず、明治の終りにはリベット結合の嗍性の 大きい構造に移行した。

ボーストリング形式も铁道では再び採用されるこ とはなく、道路橋で採用されるに止まった。

（3）東京の高架鉄道はルムシェッテル、バルッァー の指導のもとに建設が進められた。橋梁はドイツ流 のものであった。ドイツからの翰入も少星あった。 しかし、英国流から米国流へという大きな流れを変 える力は少なくとも陽な形では持たなかったように 思われる。

（4）ドイツ製トラス桁の架設・転用の状洗を明らか にし、従来の定説の修正を行った。 
（5）１００年の歳月を経て現存している析の見況を 紹介した。

\section{謝辞}

本研究のベースとなっているのは久保田敬一氏の 諭文と西村俊夫氏の諭文である。欮なる引用文献で はなく、大変多くのことをこれらに負っている。著 者らが多少のミスを指摘したとしても、いささかも その価值を減ずるものではないと信じている。

調查・政究に当たり、頚料提供、現地謂查、教示、 討議などさまざまな局面で多くの方々にお䚹話にな った。お名前を記して感謝の意を表する。

飯皇正資、大榢孝、小渠彰夫、小野田滋、金子跌

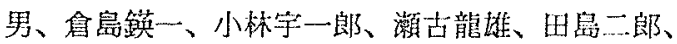
田中勇、中川浩一、成瀬輝琴、藤升都夫、村上温、 村上昌彦、吉川文夫の各氏、京都大学上木系教室図 書室、交通博物館、南海電気鉄道（儤林光夫、鈴木 康夫）、長野電跌（恩田泰造、田中守）、東京電力 猪苗代笔力所、跌道総合技術研究所、J R 東日本東 京地域本社（片寄紀雄）、同東京權㭘センター（筫 田英世）、同長野支社長野上木技術センタ一、J R 東海名古屋粠検センター、J R 西日本大阪粗检セン ターの各機関・各氏。

\section{参考文㣮}

1）日本橋梁建設協会『日本の橋』，朝會费店，19 84.6

2）松村博『大阪の權』，松籍社， 1987.5.

3）日本国有鉄道『日本国有鉄道白年史』，第 2 拳 1970.4.

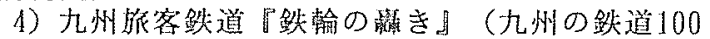
作記念誌），九州旅客猃道, 1989.10.

5）吉沢まこと「フランッ。バルツアーとその時代 の鉄道人」，島秀雄編『柬京跀誕生』，鹿鼠出版会 1990.6. 所收, p. 206 .

6）西野・小西。渕上「日本における鉄道用レール

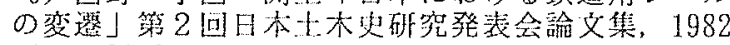
.6. p. 30-37.

7) Georg Mehrtens:Der Deutsche Brïckenbau im XIX. Jahrhundert, Z.V.D. I, Band. 44, 1900; 復刻版,
VDI-Verlag, 1984, p. 92-131.

8）久保田敬一「本邦鉄道橋梁ノ沿革二就テ」，業 務研究資料, 22-2, 鉄道大臣官房研究所, 1934

9）小西・西野・㴊上「明治時代に製作された鉄道

トラス橋の歴史と現状（第 3 報）ドイツ系トラス桁」 ，第 7 回日本土木吏研究発表会墖文集，1987.6，p. 199-206.

10）日本工業会編『明治工業史』，鉄道篇，日本工. 業会, 1926 , p. 514 .

11）日本国有鉄道九州総局編『九州の鉄道の歩み』、 日本国有鉄道九州総尚，1973.1， p. 19.

12）明治27年 7 月 31 日琴在『全国各鉄道橋梁及び遥 道明細表』，鉄道局，p. 65-74.

13）大州田瑞足「千䖪川橋梁鉄析架換工事概要」, 帝国鉄道協会会報, 15, 1914, p. 352-368.

14) H. Foerster: Taschenbuch für Bauingenieure,

4. Aufl., Verlag von Julius Springer, 1921, p. 1872 $-3$.

15）『筑後川橋梁鉄桁架換工事写真站』，（発行所， 年月の記载なし)

16）西村俊夫「国鉄トラス橋総覧」，鉄道技術研究 資料, 14-12, 1957.12.

17）守田久盛。神谷牧夫『铁道路線变せ九史揆訪 $\mathrm{N}$ 九州の鉄道 100年』，吉非蕒店，1989.2, p. 19, p.60

18) 前出 8), p. 57.

19) 前出 14), p. 1872.

20) 前 41 14), p. 1866.

21）和久田康婎「山麓温鼠鉄道」，鉄道ピクトリア

ル, No. $253,1971.7$.

22）前壮15), 写真24の綐明.

23) 前出 7), p. 83-86.

24) 前出 7), p. 102.

25) IInstructions for the Election of Link Bridges, Society Harkort System 」, 帝国鉄道協 会会報, 2, 1900, p. 391-402.

26) The Harkort Co. "The Harkort System of Pin Bridges" 1900年頃, 同社, p. 40.

27）南海電父跌道所蔵图面

28）西村俊夫「ピン結合トラス骠の変状とその対策」 ，鉄道技術研究報告，鉄道技術研究㪼，No. 483, 196 5.7 .

29）長野電鉄所藏图面

30）那波光雄「敛道淁に就て」，土㕲学全誌，12-2 , 1926. 4, p. 343-358.

31）別子銅山記念館所臀図面

32）大塚素「九州のトラス橋のルーツをたずねてく 九州鉄道とボーストリングトラス橋 $>」 ， 下 I ， 38$, 下関T.事局, 1981.3.

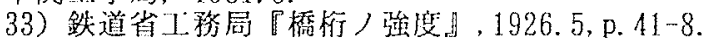

\section{ドイツ製鉄道トラス桁一覽表}

莍の䫓明

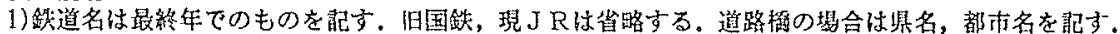

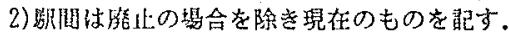

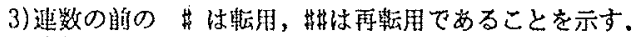

连数の次のPは下弦枋がフラットバーであることを，e梳アイバーであることを示す。

连数の次に $\mathrm{F}$ も eもないものは不明のものである。一附改造によってフラットバーとなったものである。

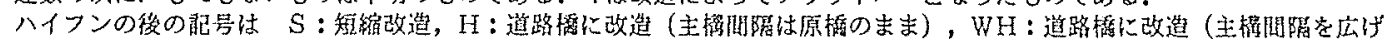

たもの) , M: 可斯標に改造。

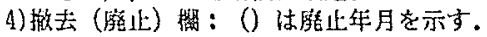




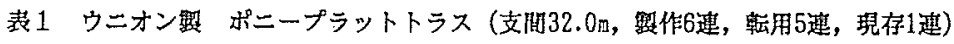

\begin{tabular}{|c|c|c|c|c|c|c|c|c|}
\hline 番号 & 铁道名線名 & 旧的道名 & 层間 & 橔梁名 & 䢤數 & 䦭通 & 撤去 (廃止) & 漕考 \\
\hline 2101 & 鹿児泉本線 & 九州鉃道 & 总拪一耽前旭 & 旭川（上り） & 1 & 1889.12 & 1914頃 & \\
\hline 2102 & 霓児自本餭 & 九为铁道 & 肥首旭一久留来 & 千藏川（上り） & 5 & 1890.3 & 1914.1 & \\
\hline 2111 & 山做淐泉鉃道 & 鹿本铁道 & 分田一来民 & 菞沲川 & $\# 4$ & 1920.8 & (1860.11) & 千歲川より \\
\hline 2112 & 作賀目 & & & & $\mathrm{H1-H}$ & 1914暊 & 不明 & 千督川より \\
\hline 2121 & （保存馓示） & & 能本鼠植木町 & （旧蒌浥川） & HH1-S & 1970 's & 玩存 & 蔡池川より \\
\hline
\end{tabular}

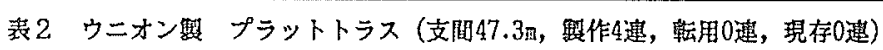

\begin{tabular}{|c|c|c|c|c|c|c|c|c|}
\hline 䊩号 & 跌道名線名 & 旧铁道名 & 欺間 & 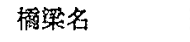 & 連数 & 開通 & \multicolumn{2}{|c|}{ 撤去（㿑止） 搹考 } \\
\hline 2201 & 䴤兒岛本線 & 九州铁道 & 肥前旭一久留米 & 千藏川（上り） & 4 & 1890.3 & 1913.12 & \\
\hline 表 3 & ハーコート盿 & \multicolumn{7}{|c|}{ 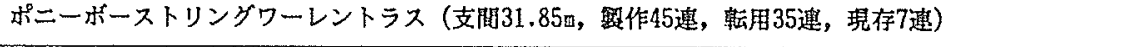 } \\
\hline 番号 & 跌道名線名 & 旧釷管名 & 影間 & 摘梁名 & 逨数 & 䦎通 & 撤去 (䧹止) & ）俏考 \\
\hline 2301 & 鹿児岛本線 & 九洲铁道 & 赤间－東鄉 & 销川（上り） & $1 F$ & 1890.9 & 1916 & 斜右 $48^{\circ} 33^{\prime}$ \\
\hline 2302 & 鹿児喝本線 & 九州鉄道 & 水智－薏賀川 & 遠賀川（上り） & $4 \mathrm{~F}$ & 1891.2 & 1911 & \\
\hline 2303 & 鹿児島本線 & 九州鳃道 & 荒木一䣨牟田 & 荒木川 & $1 \mathrm{~F}$ & 1891.4 & 1916頻 & \\
\hline 2304 & 庇児身本線 & 九州唉道 & 玉名一肥後伊倉 & 慗概本川 & IF & 1891.7 & 1916曊 & \\
\hline 2305 & 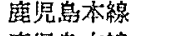 & 九州鉄道 & 玉名一肥後伊含 & 高濑川 & $4 \mathrm{P}$ & 1891.7 & 1916鋇 & \\
\hline 2306 & 施児息本線 & 九州铁道 & 上能本－焦本 & 第4 井荶川 & $1 \mathrm{p}$ & 1891.7 & 1915绕 & \\
\hline 2307 & 曼䐀本線 & 九州鉄道 & 三田川－触埼 & 田手川 & $1 P$ & 1891.8 & 1916 & \\
\hline 2308 & 层嶛本綠 & 九州铁道 & 神堵－伊賀屋 & 城原川 & $1 \mathrm{p}$ & 1891.8 & 1916垻 & \\
\hline 2309 & 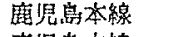 & 九科敘道 & 掜本一川层 & 白川 & $4 \mathrm{e}$ & 1894.8 & 1920嫃 & \\
\hline 2310 & 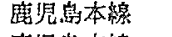 & 九州凂道 & 川尻一字士 & 加然川 & $2 e$ & 1895.1 & 1920皟 & \\
\hline 2311 & 庇児島本線 & 九州鉃道 & 川层一宇士 & 線川 & le & 1895.1 & 1921 賣 & \\
\hline 2312 & 長燎本楾 & 九州飱道 & 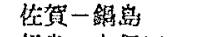 & 田有施川 & le & 1895.5 & 1915 & \\
\hline 2313 & 長踦本線 & 九州䰿道 & 踦息一久保田 & 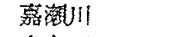 & $3 \mathrm{e}$ & 1895.5 & 1920 & \\
\hline 2314 & 镺橑本線 & 九州䬹道 & 牛溫一肥前山口 & 受久川 & le & 1895.5 & 1916 & \\
\hline 2315 & 田川湶 & 燢州铁道 & 行嚿一壆啭 & 今川 & $4 \mathrm{e}$ & 1895.8 & 1325.11 & \\
\hline 2316 & 田川線 & 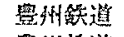 & 燢津一慰川 & 高屋川 & $1 \mathrm{e}$ & 1895.8 & 1926.2 & \\
\hline 2317 & 田川線 & 鼠州铁道 & 幦川一蛤山 & 歖多良川 & le & 1895.8 & 1924 舆 & \\
\hline 2318 & 田川觨 & 嶨州鉄道 & 䗁山一油賈原 & 第4 今月 & le & 1895.8 & $19^{--}$ & \\
\hline 2319 & 田川線 & 䁷外鉄道 & 田川知田椲内 & 彦山川 & $2 e$ & 1895.8 & 1926.5 & \\
\hline 2320 & 霹児毁本線 & 九州鹳道 & 小川一嗰在 & 水川 & le & 1896.11 & 1921筫 & \\
\hline 2321 & 日毘本線 & 舆州錐道 & 行徰一游由原 & 今川 & $4 \mathrm{e}$ & 1897.9 & 1924.3 & \\
\hline 2322 & 日毁本線 & 䀝州铁道 & 三兒門一中滶 & 经刦川 & $1 \mathrm{e}$ & 1897.9 & 1925.8 & \\
\hline 2323 & 大村線 & 九州铁道 & 月棚一小串䐚 & 川脜川 & 1e & 1888.1 & 1924.1 & 1934年まで舆峈本線 \\
\hline 2324 & 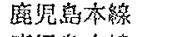 & 九州敛道 & 䦌司潜－外浜 & 問司川 & le & 1901 & $19--$ & \\
\hline 2325 & 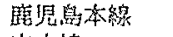 & 积道庁 & 琾瞵一折屡 & 金山川（上り） & 1 & 1908.7 & 1917 & 紏房志 $59^{\circ}$ \\
\hline 2326 & 筑术線 & 觗道序 & 造賀川裙内 & 彩川 & 1 & 1908.7 & $19--$ & 蜶为 $50^{\circ}$ \\
\hline 2331 & 山㩐霓気碳道 & 最惟珴造 & 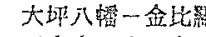 & 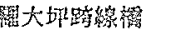 & wlp & 1914.4 & $(1971.2)$ & 現称・撤去子定、（嗝生） \\
\hline 2332 & 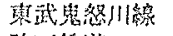 & 下野㖇道 & 下今市一大谷问 & 大谷川 & $\$ 8 \mathrm{~F}, \mathrm{e}$ & 1919 & 1966 & \\
\hline 2333 & 防不餙道 & 防石隉道 & 渖八原一㱸 & 鼠地川 & 2 & 1920.8 & $(1964)$ & \\
\hline 2334 & 国卯本線 & 锊道背 & 犬銅一管尾 & 第 2 大塄川 & HP & 1921.3 & 1939 & \\
\hline 2335 & $\begin{array}{r}\text { 上田対子䈏釷 } \\
\text { 丸子線 }\end{array}$ & 㚘子毁道 & 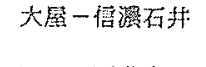 & 千些川 & $\$ 2 \mathrm{e}$ & 1928 & $(1009 ., 1)$ & 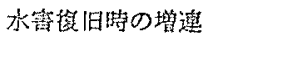 \\
\hline 2336 & $\begin{array}{l}\text { 大分交通 } \\
\text { 耶馬溪線 }\end{array}$ & $\begin{array}{l}\text { 耶，需淣 } \\
\text { 铁道 }\end{array}$ & 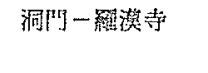 & 第 1 山国川 & $\$ 1$ & 1929 & $(1971)$ & 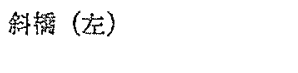 \\
\hline 2337 & 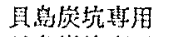 & 具鼠崖坑 & & 尽鳴川 & \$1e & $19-\cdot$ & $(1976)$ & \\
\hline 2338 & 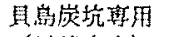 & 且毁岩坑 & & 犬嗅川 & He & $19--$ & 不明 & \\
\hline 2339 & （舆渏柿内） & 不明 & & （不明） & Hle & $19--$ & 不明 & \\
\hline 2351 & 閿桑航路 & 猞道院 & 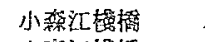 & 小箖江第 I可趿 & HIF-H & 1919 & 1942 & \\
\hline 2352 & 抣棒航路 & 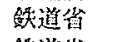 & 小㮗江磘搯 & 小秝江第 2 可勘 & MIF- & 1922 & 1942 & \\
\hline 2361 & 舆岡市方道 & 铁道覍 & （旧曼岡操事坞） & 第 2 上条咑道踦 & $\$ 2 e^{-W H}$ & 1931 質 & 現用 & \\
\hline 2362 & 川㱦市市道 & 铁道省 & 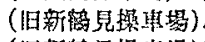 & 小靚踦 & $37 \mathrm{e}-\mathrm{HH}$ & 1929 䨘 & $19-$. & \\
\hline 2363 & 川㥓市市道 & 铁道省 & (旧新鹤見㙅軎埸) & 御幸跨 & $\# 1 \mathrm{e}-W H$ & 1929垻 & $19-$ & \\
\hline 2364 & 明石市施道 & 餚道省 & （西明石知） & 小久保跨 & $\# 2 \mathrm{e}-\mathrm{H}$ & 1930.3 & 現用 & \\
\hline 2365 & 鼠栖市市道 & 铁道省 & （旧尊栖㩭事埸） & - - 路 & $\$ 2 e^{-W H}$ & $19--$ & $19-$ & \\
\hline 2371 & 長野䝿累道 & 曼野惧 & （大町市） & 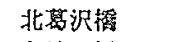 & "We-H & 1921 & 1977缜 & \\
\hline 2372 & 山口㗨县道 & 山口累 & (钴坮时) & 島地川虂 & 㻤2 - & 1960 's & 1981 & 防石鉄道島地川を改䓀 \\
\hline 2373 & 上田市标道 & 上田方 & （上田柿） & 大石摘 & $\# \# 2 e-H$ & 1971.3 & 現用 & 上田丸子干曲川を改䔩 \\
\hline
\end{tabular}




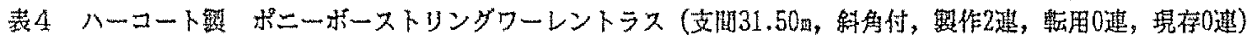

\begin{tabular}{|c|c|c|c|c|c|c|c|c|}
\hline 䇛号 & 飭避名線名 & 回唉道名 & 翼谓 & 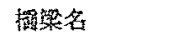 & 遠数 & 䦎道 & \multicolumn{2}{|c|}{ 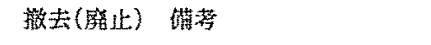 } \\
\hline 2401 & 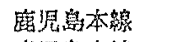 & 九州铁道 & 遠蕒川籊内 & 新川（上り） & $1 \mathrm{~F}$ & 1890.11 & 1916 & \multirow{2}{*}{ 解奥方 $60^{\circ} 40^{\prime}$} \\
\hline 2402 & 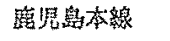 & 九州铕道 & 鼠崎一折尾 & 全山川 (下り) & $1 \mathrm{~F}$ & 1891.2 & 1917 & \\
\hline 器 5 & ハーコート製 & \multicolumn{7}{|c|}{ 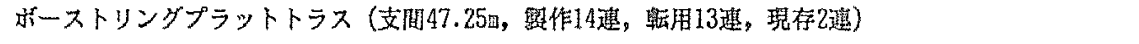 } \\
\hline 貿费 & 䇴道名繶名 & 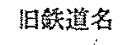 & 期開 & 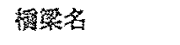 & 速嫩 & 閔通 & \multicolumn{2}{|c|}{ 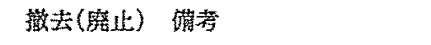 } \\
\hline 2501 & 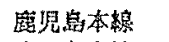 & 九州的道 & 水巻一透知川 & 遠贺川（上り） & $5 \mathrm{~F}$ & 1891.2 & 1911 & \\
\hline 2502 & 鹿児急本線 & 九州道 & 竦小叒－湖高 & 知部川 & $2 \mathrm{~F}$ & 1891.4 & 1916综 & \\
\hline 2503 & 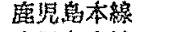 & 九州鱕道 & 玉名一肥後伍食 & 高潞川 & $4 F$ & 1881.7 & 1916 頃 & \\
\hline 2504 & 欀児島本線 & 九州铁道 & 川劦一宇土 & 加勢川 & le & 1895.1 & 191964 & \\
\hline 2505 & 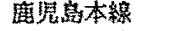 & 九州鉄道 & 川㤅一字土 & 橉川 & le & 1895.1 & 1921装 & \\
\hline 2506 & 鹿児島本線 & 九州铁道 & 川层一宇土 & 浜戸川 & le & 1895.1 & 1919賸 & \\
\hline 2511 & 足星線 & 足尾鉄道 & 間藤一足尾本山 & 出川 & $\$ 1 \mathrm{~F}$ & 1914 & 1953 & \\
\hline 2512 & 足鼠線 & 足尾䱃望 & 間蓝一足尾木山 & 第 2热木川 & $\| \mathrm{HP}$ & 1914 & 1953 & \\
\hline 2513 & 東弐鬼怒川線 & 下野競道 & 大登一新高媳 & 鬼怒川 & $\# 2 \mathrm{~F}$ & 1917 & 1972.11 & \\
\hline 2514 & 東武鬼怒川線 & 下野较道 & 大叠一新高钝 & 䂼川 & $\$ 1 F$ & 1917 & 1946 & \\
\hline 2515 & 東毁铁道 & 来野鉄嚾 & 大田原－中田原 & 蛇尾川 & $\$ 1 F$ & 1918 & 1968 & \\
\hline 2516 & 䁂肥本镜 & 䶃道筸 & 犬蚐一菅尾 & 第 2 大瑇川 & $A 1 F-R$ & 1921 & 1939 & 補强 \\
\hline 2517 & 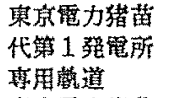 & 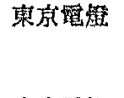 & （福島罢） & 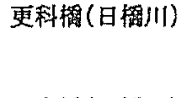 & $\# 1 F$ & $1921 ?$ & 1987 檟 & \\
\hline 2518 & 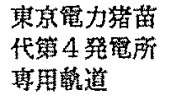 & 東宗琵椥 & （福岛孯） & 切立橧(日搞川) & $\$ 1 F$ & 1921 & 現用 & - \\
\hline 2519 & 雇山線 & 䀢道背 & 大金一小增 & 荒川 & $\$ 1$ & 1823 & 1953 & \\
\hline 2520 & 南短電気㪘道 & 高路铁选 & 楮本一紀伊潜水 & 紀ノ川 & $\# 1-F$ & 1924 & 1969.4 & 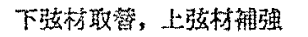 \\
\hline 2531 & 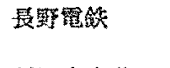 & 河察铁道 & 井上一猪肘 & 市川(臽々川) & $\$ 1-S$ & 1922 & 1974 & 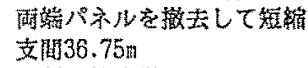 \\
\hline 2541 & 积讯市市道 & 䠲道省 & & 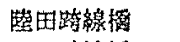 & $\# 1 \mathrm{e}-H$ & 1923頃 & 現用 & 旧䄶沢鼠莗埸， \\
\hline 2542 & 道方柿访道 & 铁道畕 & & - - 跨缐竅 & $\$ H 1 F-W H$ & 1942留 & $19 \cdots$ & 谓方欺，第 2 大野川より \\
\hline
\end{tabular}

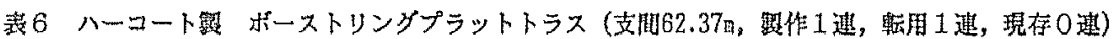

\begin{tabular}{|c|c|c|c|c|c|c|}
\hline 番是 & 筷道名䍃名 & 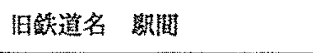 & 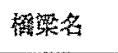 & 迲数 & 琶通 & 撤去（繁止）借落 \\
\hline 2601 & 田川線 & 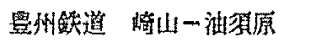 & 第 2 今川 & 10 & 1895.8 & 1926 \\
\hline 2611 & 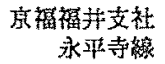 & 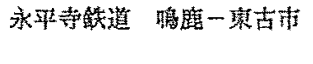 & 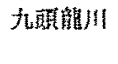 & 粦le & 1929.12 & $(1969.9)$ \\
\hline
\end{tabular}

\begin{tabular}{|c|c|c|c|c|c|c|c|c|}
\hline 瑟号 & 邹遄名缐名 & 旧铁道名 & 影閣 & 蘩梁名 & 這数 & 䦎通 & 撤去(廃止) & 储考 \\
\hline 270 & 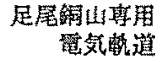 & 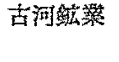 & (足箠时) & 古河搆（松本川） & $1 F H$ & 1891.1 & 現用 & \\
\hline
\end{tabular}

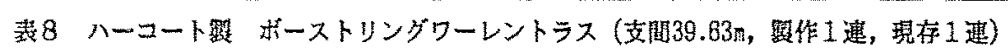

\begin{tabular}{|c|c|c|c|c|c|c|c|c|}
\hline 蕃号 & 飭道名線名 & 旧铁道名 & 欺䀦 & 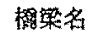 & 連数 & 䦎通 & 撤去（廃止） & 傥考 \\
\hline 2801 & 別子钩山铁道 & 往友金堄 & 緛出埸附近 & 足谷川 & le & 1893.5 & (1977.1)見存 & 斜角右 $60^{\circ}$ ，国領川 \\
\hline
\end{tabular}

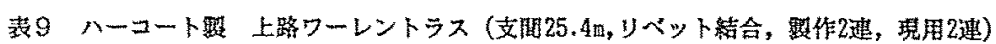

\begin{tabular}{|c|c|c|c|c|c|c|c|c|}
\hline 凅号 & 涂道名線名 & 旧铁道名 & 駱間 & 霞梁名 & 荤数 & 開通 & 撤去（發比） & 第考 \\
\hline 2901 & 中央本線 & 甲武䂠道 & 水道摇一饭飯拱 & 小石川(緩行) & 2線电 1 & 1904 & 現用 & \\
\hline
\end{tabular}

